Codes for Computers and Microprocessors 
Also from The Macmillan Press

Analysis and Design of Sequential Digital Systems

L. F. Lind and J. C. C. Nelson

An Introduction to Digital Logic

A. Potton

Digital Circuits for Binary Arithmetic

R. M. M. Oberman 


\section{Codes for Computers and Microprocessors}

P.E. Gosling

Q.L.M.Laarhoven 
๑ P. E. Gosling and Q. L. M. Laarhoven 1980

All rights reserved. No part of this publication may be reproduced or transmitted, in any form or by any means, without permission.

First published 1980 by

THE MACMILLAN PRESS LTD

London and Basingstoke

Associated companies in Delhi Dublin

Hong Kong Johannesburg Lagos Melbourne

New York Singapore and Tokyo

\section{British Library Cataloguing in Publication Data}

Gosling, P E

Codes for computers and microprocessors.

1. Electronic digital computers

2. Coding theory

I. Title II. Laarhoven, Q L M

001.6 '424 QA76.5

ISBN 978-1-349-04372-9

ISBN 978-1-349-04370-5 (eBook)

DOI 10.1007/978-1-349-04370-5

This book is sold subject to the standard conditions of the Net Book Agreement.

The paperback edition of this book is sold subject to the condition that it shall not, by way of trade or otherwise, be lent, resold, hired out, or otherwise circulated without the publisher's prior consent in any form of binding or cover other than that in which it is published and without a similar condition including this condition being imposed on the subsequent purchaser. 


\section{Contents}

Preface vii

Introduction $\quad$ ix

1 Weighted Codes 1

1.1 Properties 2

$\begin{array}{lll}1.2 & \text { Some conversion examples } & 3\end{array}$

1.3 Conversion of base $g$ to decimal 3

1.4 Arithmetic rules for binary numbers 4

1.5 Word length 4

1.6 Conversion of decimal to binary 5

$\begin{array}{lll}1.7 & \text { Other notation forms for binary codes } & 6\end{array}$

$\begin{array}{lll}1.8 & \text { Octal number system } & 7\end{array}$

1.9 Fractions 9

$\begin{array}{ll}1.10 \text { Negative numbers } & 11\end{array}$

$\begin{array}{ll}1.11 \text { Binary addition } & 15\end{array}$

$\begin{array}{ll}1.12 \text { Subtraction using complements } & 16\end{array}$

2 Organisation of the Central Processing Unit 18

$\begin{array}{lll}2.1 & \text { Multiplication } & 19\end{array}$

$\begin{array}{lll}2.2 \text { Division } & 21\end{array}$

$\begin{array}{lll}2.3 & \text { Logical operations } & 23\end{array}$

3 Floating Point 25

3.1 Use of numbers 25

$\begin{array}{lll}3.2 & \text { Integer storage } & 28\end{array}$

4 Practical Coding Procedures 30

$\begin{array}{lll}4.1 \quad 8-4-2-1 \text { code } & 30\end{array}$

4.2 Excess-3 code 31

$\begin{array}{lll}4.3 & \text { Gray code } & 32\end{array}$

4.4 Unweighted codes 33 
$\begin{array}{lll}4.5 & \text { ISO code } & 35\end{array}$

$\begin{array}{lll}4.6 & \text { ASCII code } & 36\end{array}$

4.7 EBCDIC code $\quad 38$

4.8 Telex code $\quad 39$

4.9 Punched tape $\quad 40$

4.10 Baudot code $\quad 40$

4.11 Punched cards $\quad 42$

5 Data Transmission 47

$\begin{array}{lll}5.1 & \text { Transmission systems } & 47\end{array}$

$\begin{array}{ll}5.2 \text { Parity checking } & 49\end{array}$

5.3 Magnetic tape codes 49

Summary of EBCDIC and ASCII Codes

USASCII Character Set $\quad 56$

Hexadecimal-Decimal Integer Conversion Table 58 


\section{Preface}

This book is about communication - communication between man and machines, and between machines themselves. It is intended to be as much a reference book as a textbook to serve as part of a course of study. On the one hand it will be useful in a practical sense for many people working, in particular, with minicomputers and now microprocessors. In both of these an understanding of what is going on inside is an aid to using the machines efficiently. On the other hand it will also be of value to students of computer science who need to be familiar with the techniques of data transmission. We hope that this book will add a practical dimension to the pure theory that is to be found in many textbooks dealing with computer science at all levels.

P. E. GOSLING

Q. L. M. LAARHOVEN 


\section{Introduction}

The ability to exchange information between men and computers, and between computers themselves, relies on symbols which have a definite meaning agreed and arranged between both parties beforehand. Such symbols must have the same meaning for both partners in order to avoid any confusion or misinterpretation. The agreement on the meaning of the symbols used is usually built into the computer and learned by man. The series of agreements which represents the elements of a collection for communication is referred to as a code, and man has used symbols and codes for many years. For example, traffic lights and traffic signs together form a code which consist of a series of agreements about traffic behaviour. Another example is the Morse code which is a well known time-based code representing numbers and the letters of the alphabet.

The choice of a code for a given application depends on several factors. One of these is the suitability of the code for arithmetic calculation, another is the ability to detect mistakes and correct them. Modern computers only recognise the two symbols 1 and 0 because these are easily represented by electronic equipment. Our task in this book is to show some of the ways in which a variety of information can be contained in patterns which consist solely of $1 \mathrm{~s}$ and $0 \mathrm{~s}$.

\section{DATA REPRESENTATION}

Codes can take any form as required by the user but in general they can be thought of as a mapping from a set of symbols $A$ to a set of symbols $B$ by a transformation according to some rule.

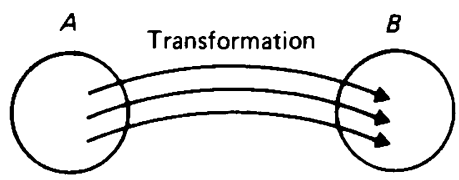

$A$ : Symbols recognisable by man

$B$ : Symbols recognised by a computer

Information intelligible to man will consist of a set of symbols of which the letters of the alphabet and the digits 0 to 9 form a large part. The computer, however, operates through a series of electronic switches designed to allow current 
to flow or not flow. Such a switch provides two possible options

Current/no current

which translates to

$$
\begin{gathered}
\text { yes/no } \\
\text { on/off } \\
1 / 0
\end{gathered}
$$

such a unit of information is called a bit (binary information digit).

There are a number of standard codes used to convey information through binary coding. One of these is the American Standard Code for Information Interchange (ASCII); another is the Extended Binary Coded Decimal Interchange Code (EBCDIC) and these will be discussed in detail later.

The result of coding a piece of information is called the object code and it is the purpose of all coding to produce an object code in binary digits for any combination of the 26 alphabetic characters, the digits 0 to 9 , certain punctuation marks, graphical characters and arithmetic operators $(+,-;=\ldots .$.$) together with what are$ termed control characters. A control character is one which represents an instruction to a certain piece of computer hardware, for example

\section{Transmit/receive}

Device control

Code extension control

Information separators

A code in binary form can represent any number of symbols provided that for every possible symbol there exists a unique binary code.

If only one binary digit can be used in an object code then there are only $2^{1}$ combinations possible ( 0 or 1 ). If more than one binary digit is allowed then for $n$ bits there are $2^{n}$ combinations possible. For example, if $n=3$ there are $2^{3}=8$ combinations possible

$$
000,001,010,011,100,101,110,111
$$

so that from 3 bits there are 8 possible object code patterns.

The more characters we need to represent, the greater the number of bits we need to use in order to distinguish between letters, figures, punctuation marks and special characters. The bits must be put together in such a way that there is no doubt as to their meaning. A sequence of bits are put together to form all or part of a computer word. If a word consists of eight bits

\begin{tabular}{|l|l|l|l|l|l|l|l|}
\hline b0 & b1 & b2 & b3 & b4 & b5 & b6 & b7 \\
\hline
\end{tabular}

b7, the rightmost bit is called the least significant bit (LSB) and the leftmost bit, b0, is called the most significant bit (MSB). 